\title{
HUBUNGAN PENERAPAN SISTEM PENGGAJIAN DENGAN KOMITMEN DAN PRODUKTIVITAS KARYAWAN PT. DWIPAHASTA UTAMADUTA
}

\author{
Priyo Tri Nugroho*)1, Syamsul Maarif**), dan Joko Affandi**) \\ *) Sekolah Bisnis, Institut Pertanian Bogor \\ Jl. Raya Pajajaran, Bogor 16151 \\ **) PPM Manajemen \\ Jl. Menteng Raya No. 9 Jakarta Pusat 10340
}

\begin{abstract}
The objective of the research is to discover the perception of the employee on the implementation of payroll system in PT Dwipahasta Utamaduta; know the relationship between the implementation of payroll system with the commitment of PT Dwipahasta Utamaduta employee and give a policy solution. The research uses qualitative and quantitative approach. To analyze the relationship, the research used Rank Spearman to analyze the existing or non-existing inter variable correlation. The result of the research shows that 1) most of the employee knows, understands, and feels the payroll system implementation is suitable with the real condition; 2) a one way relation and significant relationship between the payroll system with the commitment of the employee; 3) a one way relation and significant relationship between the payroll system with the productivity of the employee; 4) the management implements consistently the payroll system and evaluates periodically.
\end{abstract}

Keywords: commitment, semantic difference, productivity, payroll system

\begin{abstract}
ABSTRAK
Penelitian ini bertujuan mengetahui persepsi karyawan terhadap penerapan sistem penggajian di PT Dwipahasta Utamaduta; mengetahui hubungan antara penerapan sistem penggajian dengan komitmen karyawan PT Dwipahasta Utamaduta; mengetahui hubungan antara penerapan sistem penggajian dengan produktivitas kerja karyawan PT Dwipahasta Utamaduta; dan memberikan solusi kebijakan yang seharusnya diambil perusahaan. Pendekatan penelitian menggunakan kualitatif dan kuantitatif. Uji korelasi menggunakan korelasi Rank Spearman untuk menganalisis ada tidaknya hubungan antar variabel. Hasil penelitian menunjukkan bahwa 1) mayoritas karyawan mengetahui, memahami dan merasakan sistem penggajian yang diterapkan sudah sesuai kondisi yang sebenarnya; 2) hubungan yang searah dan signifikan antara sistem penggajian dengan komitmen karyawan; 3) hubungan yang searah dan signifikan antara sistem penggajian dengan produktivitas karyawan; 4) manajemen secara konsisten menerapkan sistem penggajian dan dievaluasi secara berkala.
\end{abstract}

Kata kunci: komitmen, perbedaan semantik, produktivitas, sistem penggajian

\footnotetext{
${ }^{1}$ Alamat Korespondensi:

Email: priyook_3ends@yahoo.co.id
} 


\section{PENDAHULUAN}

Pengelolaan sumber daya manusia yang efektif adalah kunci dari keberhasilan sebuah kinerja organisasi dalam mencapai tujuannya. Visi dan misi perusahaan dijabarkan dalam sebuah strategi untuk mencapai tujuan perusahaan. Manajemen sumber daya manusia merupakan penerapan pendekatan sumber daya manusia di mana bersama-sama terdapat dua tujuan yang ingin dicapai yaitu tujuan perusahaan dan tujuan karyawan (Mangkuprawira, 2002).

Perusahaan dalam mencapai tujuan salah satunya melalui penerapan sistem penggajian yang tepat dan efektif sehingga mampu meningkatkan produktivitas atau kinerja karyawan. Produktivitas kerja seseorang biasanya terwujud sebagai prestasi karyawan tersebut di lingkungan kerjanya di sisi lain, produktivitas pada dasarnya adalah suatu sikap mental yang selalu mempunyai pandangan bahwa mutu kehidupan hari ini harus lebih baik dari kemarin. Penilaian prestasi kerja perlu dilakukan secara formal berdasarkan serangkaian kriteria yang ditetapkan secara obyektif serta didokumentasikan secara sistematik (Siagian, 1995).

Hasil studi Lawler (1983) tentang masalah pengupahan menunjukkan bahwa sistem penggajian yang efektif akan memengaruhi tingkat kehadiran karyawan, produktivitas dan mutu pekerjaan karyawan, serta prestasi dan perilaku lainnya yang mempunyai dampak menyeluruh terhadap organisasi atau perusahaan. Sistem penggajian yang baik dapat memotivasi karyawan untuk pencapaian tujuan perusahaan. Namun, apabila sistem penggajian tersebut tidak efektif dalam penerapannya akan mengakibatkan situasi yang lebih buruk dan berakibat apa yang menjadi tujuan perusahaan tidak tercapai.

Penerapan sistem pengajian diharapkan karyawan mempunyai komitmen yang tinggi terhadap organisasi. Ketika komitmen karyawan telah tinggi maka efektivitas sumber daya organisasi secara umum akan meningkat. Komitmen merupakan bagian kunci dalam manajemen sumber daya manusia. Komitmen tidak hanya dilakukan oleh karyawan, tetapi juga pihak manajemen dalam menjalankan kebijakan-kebijakan yang telah ditetapkan bersama. Penegakan aturan-aturan perusahaan menjadi sangat penting dalam membangun kepercayaan dan kejujuran dalam organisasi secara menyeluruh (Simamora, 1999).
Allen dan Meyer (1997) sebagaimana dikutip oleh Umar (2010) mendefinisikan bahwa komitmen organisasi sebagi sebuah konsep yang merefleksian tiga dimensi utama, yang pertama affective commitment (komitmen afektif) menggambarkan seberapa jauh tingkat emosi terikat, mengenal, dan keterlibatan seorang karyawan dalam organsisasi, kedua normative commitment (komitmen normative) menggambarkan seberapa jauh tingkat perasaan terikat untuk menjadi karyawan dari sebuah organisasi yang didasarkan kepada perasaan seperti kesetiaan, afeksi, kehangatan, pemilikan, kebanggaan, kesenangan, kebahagian, dan lain-lain, ketiga continuance commitment (komitmen kelanjutan) menggambarkan seberapa jauh tingkat kesadaran terikat untuk menjadi karyawan dari sebuah organisasi dan akan merasa rugi apabila meninggalkan organisasi tersebut.

Menurut Umar (2005), produktivitas adalah perbandingan antara hasil yang dicapai (output) dengan keseluruhan sumber daya yang digunakan (input) dan dapat dinyatakan dalam ukuran fisik ukuran finansial. Dengan kata lain produktivitas memiliki dua dimensi, yaitu yang pertama efektivitas yang mengarah pada pencapaian untuk kerja maksimal, yaitu pencapaian target yang berkaitan dengan kualitas, kuantitas dan waktu, yang kedua efisiensi yang berkaitan dengan upaya membandingkan input dengan realisasi penggunaannya atau bagaimana pekerjaan tersebut dilaksanakan.

Perusahaan melakukan perubahan sistem penggajian dan mulai diterapkan pada pertengahan tahun 2015, dengan adanya perubahan penggajian diharapkan mampu meningkatkan komitmen dan produktivitas kerja karyawan. Namun, setelah diterapkannya sistem penggajian tersebut tingkat kehadiran karyawan dan produktivitas belum menunjukkan perubahan yang berarti. Tingkat kehadiran karyawan masih rendah sebesar 95\% dibawah target perusahaan, yaitu 98\% dan tingkat produktivitas juga masih cukup rendah.

Penelitian sebelumnya juga dilakukan oleh Hameed (2014), Ketabi dan Tahmasebi (2015), Rezaei (2015), Wiantara (2014), Dewi (2014), Kibitsu et al. (2014), Anvari etal. (2014), Yamoah (2014), Saqib etal. (2015), Katua et al. (2014), Wilfred et al. (2014), Umar (2010) dan Onyije (2015), hasil penelitian menunjukkan sistem kompensasi mempunyai pengaruh yang signifikan terhadap produktivitas kerja karyawan. Kemudian dalam penelitian Osa dan Amos (2014), Dixit dan 
Bhati (2012) hasil penelitian menunjukkan komitmen berpengaruh signifikan terhadap produktivitas kerja karyawan. Rizal et al. (2014) dan Huang et al. (2014) hasil penelitian menemukan bahwa sistem kompensasi berpengaruh tetapi tidak secara langsung terhadap produktivitas kerja karyawan, sedangkan Wekesa dan Nyaroo (2013) mempunyai hasil penelitian yang berbeda yaitu bahwa kompensasi tidak mempunyai pengaruh terhadap kinerja karyawan.

Penelitian bertujuan mengetahui persepsi karyawan terhadap penerapan sistem penggajian di PT Dwipahasta Utamaduta; mengetahui hubungan antara penerapan sistem penggajian dengan komitmen karyawan PT Dwipahasta Utamaduta; mengetahui hubungan antara penerapan sistem penggajian dengan produktivitas kerja karyawan PT Dwipahasta Utamaduta; dan memberikan solusi kebijakan yang seharusnya diambil perusahaan.

\section{METODE PENELITIAN}

Pendekatan penelitian menggunakan kualitatif dan kuantitatif. Pendekatan kualitatif dengan analisis deskriptif untuk menjelaskan persepsi karyawan terhadap sistem penggajian dan hubungannya dengan komitmen dan produktivitas karyawan PT Dwipahasta Utamaduta. Pendekatan kuantitatif untuk menjelaskan arah dan kuatnya hubungan antar variabel yang diteliti. Data yang diperlukan dalam penelitian ini adalah data primer dan data sekunder. Data primer diperoleh melalui wawancara dan penyebaran kuesioner, sedangkan data sekunder bentuknya laporan bulanan dari internal perusahaan.

Penelitian dilakukan di PT Dwipahasta Utamaduta beralamat di Jalan Yos Sudarso Kav 45-47 Tanjung Priok Jakarta Utara. Waktu penelitian dimulai bulan November 2015 sampai dengan Desember 2015 hal ini dilakukan untuk mengevaluasi penerapan sistem penggajian setelah lima bulan diterapkan. Responden dalam penelitian ini adalah seluruh karyawan PT Dwipahasta Utamaduta berjumlah 106 karyawan dari semua divisi (sensus).

Variabel yang digunakan dalam penelitian ini terdiri dari tiga variabel, yaitu variabel sistem penggajian, variabel komitmen dan variabel produktivitas. Setiap variabel mempunyai indikator-indikator penelitian seperti tertuang dalam Tabel 1.
Tabel 1 Variabel, definisi dan indikator

\begin{tabular}{|c|c|c|}
\hline Variabel & Definisi & $\begin{array}{l}\text { Indikator } \\
\text { Penelitian }\end{array}$ \\
\hline $\begin{array}{l}\text { Sistem } \\
\text { Penggajian } \\
\text { (Surat } \\
\text { Keputusan } \\
\text { Direksi } \\
\text { No.DHU/ } \\
\text { Dir. 044/ } \\
\text { SK/6.2015) }\end{array}$ & $\begin{array}{l}\text { Sekumpulan prosedur } \\
\text { yang mengatur } \\
\text { besaran gaji berdasar } \\
\text { kelas jabatan dan } \\
\text { skala gaji }\end{array}$ & $\begin{array}{l}\text { 1. Kelas jabatan } \\
\text { 2. Skala gaji } \\
\text { 3. Pedoman } \\
\text { kenaikan kelas } \\
\text { jabatan } \\
\text { 4. Komponen } \\
\text { gaji } \\
\text { 5. Tunjangan } \\
\text { kesejahteraan }\end{array}$ \\
\hline $\begin{array}{l}\text { Komitmen } \\
\text { (Allen dan } \\
\text { Meyer, 1997) }\end{array}$ & $\begin{array}{l}\text { Komitmen berarti } \\
\text { ada suatu tindakan, } \\
\text { dedikasi dan kesetian } \\
\text { seseorang pada janji } \\
\text { yang telah dinyatakan } \\
\text { untuk memenuhi } \\
\text { tujuan organisasi dan } \\
\text { individunya }\end{array}$ & $\begin{array}{l}\text { 1. Affective } \\
\text { commitment } \\
\text { 2. Normative } \\
\text { commitment } \\
\text { 3. Continuance } \\
\text { commitment }\end{array}$ \\
\hline $\begin{array}{l}\text { Produktivitas } \\
\text { Kerja (Umar, } \\
\text { 2005) }\end{array}$ & $\begin{array}{l}\text { Perbandingan antara } \\
\text { output atau hasil } \\
\text { dalam waktu tertentu } \\
\text { dengan sumber } \\
\text { daya (input) yang } \\
\text { digunakan }\end{array}$ & $\begin{array}{l}\text { 1.Efektivitas } \\
\text { 2. Efisiensi }\end{array}$ \\
\hline
\end{tabular}

Visi dan Misi perusahaan diimplementasikan dalam bentuk perilaku dan budaya yang melekat dalam suatu organisasi tersebut. Keberadaan sumber daya manusia sebagai pelaksana visi dan misi perusahaan adalah hal yang vital demi tercapainya tujuan perusahaan maupun karyawan. Oleh karena itu, sumber daya manusia adalah unsur penting yang berhubungan dengan pelaksanaan fungsi manajemen sumber daya manusia secara efektif dan efisien. Pengelolaan sumber daya manusia yang baik akan mewujudkan visi dan misi serta tujuan perusahaan.

Indikator sistem penggajian meliputi kelas jabatan, skala gaji, pedoman kenaikan kelas jabatan, komponen gaji, tunjangan kesejahteraan, Surat Keputusan Direksi No. DHU/Dir. 044/SK/6.2015. Indikator komitmen meliputi affective commitment, normative commitment, continuance commitment (Allen dan Meyer, 1997). Indikator produktivitas meliputi efektivitas dan efisiensi (Umar, 2005). Untuk memberikan pemahaman yang lebih baik maka kerangka pemikiran konseptual yang dibangun dalam penelitian ini dapat dilihat pada Gambar 1. 


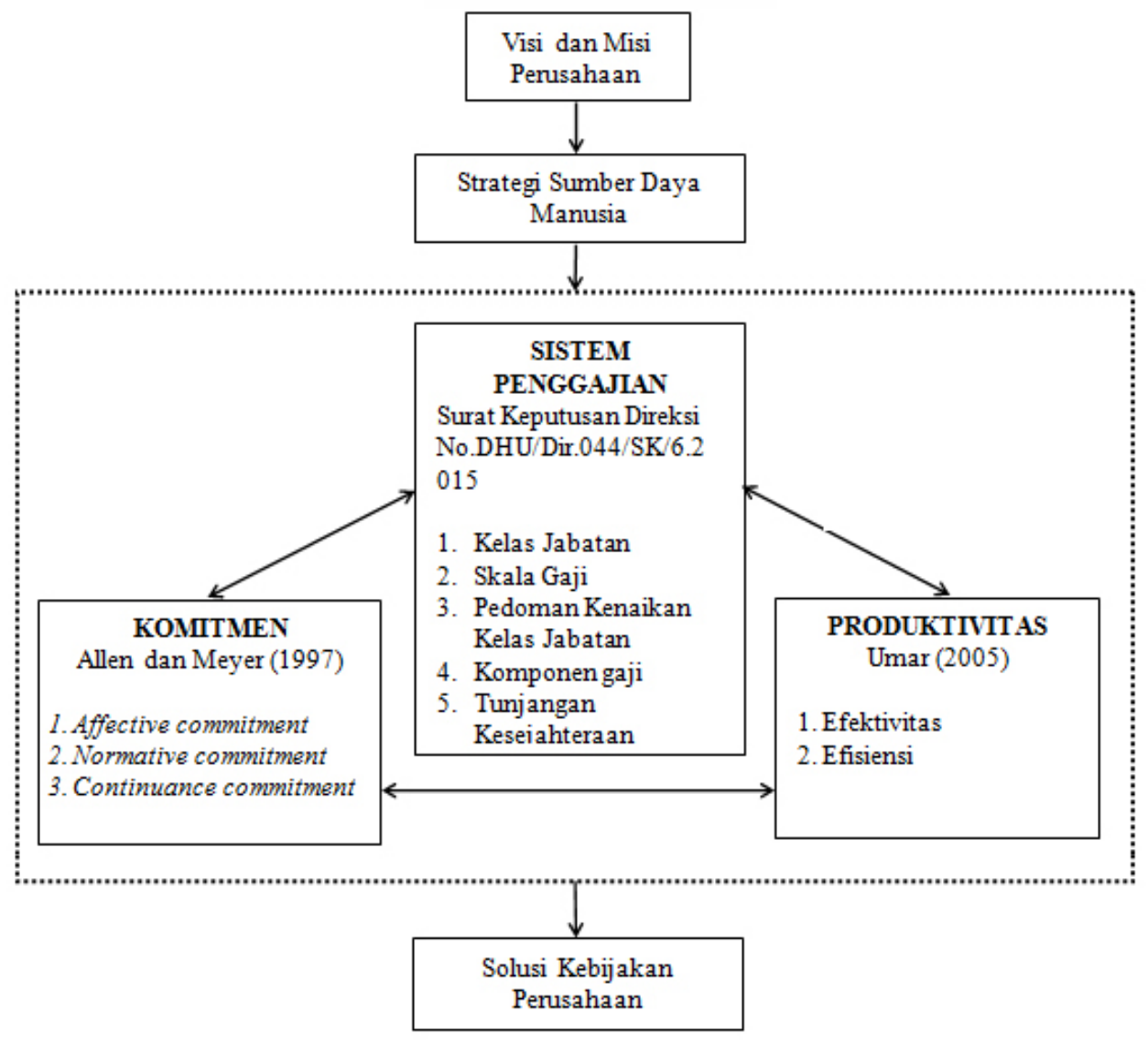

Gambar 1 Kerangka pemikiran penelitian

Penelitian didasarkan dengan kajian teori dan kajian peneliti-peneliti sebelumnya serta dari beberapa jurnal ilmiah yang ada relevansinya dengan sistem penggajian, komitmen dan produktivitas. Persepsi sistem penggajian di perusahaan diperoleh dari karyawan melalui persepsi terhadap indikator-indikator penelitian variabel sistem penggajian yang selama ini diterapakan di perusahaan. Selanjutnya, persepsi mengenai variabel komitmen dan produktivitas berdasarkan persepsi karyawan terhadap indikator yang ada dalam variabel tersebut berdasarkan teori yang digunakan.

Setelah data diolah maka diketahui indikator-indikator mana yang mempunyai frekuensi nilai yang sering muncul. Dari hasil tersebut maka dapat dideskripsikan hasil penelitian sesuai dengan data yang ada untuk menjawab pertanyaan penelitian. Uji validitas digunakan untuk sejauh mana ketepatan dan kecermatan suatu alat ukur dalam melaksanakan fungsi ukurnya dan uji reliabilitas digunakan sebagai alat pengukur didasarkan pada pembandingan atau komparasi antara hasil-hasil pengukuran yang dilakukan secara berulangulang pada sejumlah subjek yang sama. Uji korelasi menggunakan korelasi rank spearman yang bertujuan untuk menganalisis ada tidaknya hubungan yang erat antara variabel penerapan sistem penggajian dengan komitmen dan produktivitas kerja karyawan dengan mengukur seberapa besar derajat keeratan hubungan antara variabel yang diamati (Djarwanto, 2001).

\section{HASIL}

Berdasarkan isian kuesioner dari 106 responden dengan sembilan macam karakteristik, disampaikan mayoritas responden dari masing-masing kriteria (Tabel 2).

Tabel 2 Karakteristik responden

\begin{tabular}{llc}
\hline \multicolumn{1}{c}{ Keterangan } & \multicolumn{1}{c}{ Kriteria } & $\begin{array}{c}\% \\
\text { (persen) }\end{array}$ \\
\hline Usia & 31-35 Tahun & 20,75 \\
Jenis kelamin & Laki-laki & 94,34 \\
Status pernikahan & Menikah & 83,02 \\
Pendidikan & SMA/Sederajat & 62,26 \\
Divisi & Terminal Peti Kemas & 66,98 \\
Masa kerja & 8-11 Tahun & 35,85 \\
Kelas jabatan & 1-2 & 85,85 \\
Status hubungan kerja & Tetap & 84,91 \\
Skala gaji & 3-6 Juta & 85,85 \\
\hline
\end{tabular}


Berdasarkanujivaliditas terhadap pernyatan-pernyataan pada sistem penggajian, komitmen dan produktivitas diperoleh nilai $r$ hitung atau korelasi lebih besar dari $r$ tabel untuk $n=30$ dengah alpha $5 \%$ sebesar 0,361 sehingga semua butir pernyataan valid. Ketiga variabel juga dinyatakan reliabel karena nilai alpha cronbach lebih besar dari cut value 0,70 berturut-turut sebesar $0,903,0.843$ dan 0,819 .

\section{Persepsi Responden terhadap Variabel Penggajian, Komitmen, dan Produktivitas}

Persepsi karyawan terhadap variabel sistem penggajian diperoleh melalui frekuensi angka yang sering muncul pada setiap indikator, dari kelima indikator diperoleh angka yang sering keluar adalah empat (Tabel 3). Hal ini dapat diartikan bahwa mayoritas karyawan secara umum mengetahui, memahami dan merasakan bahwa sistem pengajian sudah sesuai diterapkan di perusahaan.

Persepsi terhadap variabel komitmen diperoleh melalui frekuensi angka yang sering muncul pada setiap indikator, dari ketiga indikator angka 5 sering muncul pada indikator affective commitment dan normative sedangkan angka 4 sering muncul pada indikator continuance commitment (Tabel 4). Secara umum mayoritas karyawan memahami komitmen dengan baik.

Persepsi terhadap variabel produktivitas diperoleh melalui frekuensi angka yang sering muncul pada setiap indikator, dari kedua indikator angka 5 sering muncul pada indikator efektivitas sedangkan angka 4 sering muncul pada indikator efisiensi (Tabel 5). Secara umum mayoritas karyawan memahami produktivitas dengan baik.

Hasil korelasi analisis rank spearman untuk mengetahui hubungan sistem penggajian dengan komitmen dan produktivitas dijelaskan dalam Tabel 6 . Hal ini menunjukkan bahwa hubungan antara penerapan sistem penggajian dengan komitmen adalah positif dan signifikan. Hasil uji korelasi diperoleh nilai korelasi sebesar 0,515 dengan p-value $(0,000)$. P-value lebih kecil dari alpha 5\% artinya terdapat hubungan yang positif dan signifikan antara penerapan sistem penggajian dengan komitmen karyawan. Dapat dijelaskan bahwa semakin baik persepsi karyawan terhadap penerapan sistem penggajian maka akan semakin tinggi komitmen karyawan terhadap perusahaan.

Tabel 3 Persepsi responden terhadap variabel sistem penggajian

\begin{tabular}{lcccccc}
\hline & \multicolumn{5}{c}{ Frekuensi } & \multirow{2}{*}{ Modus } \\
\cline { 2 - 6 } \multicolumn{1}{c}{ Indikator } & 1 & 2 & 3 & 4 & 5 & \\
\hline Kelas jabatan & 20 & 12 & 21 & 37 & 16 & 4 \\
Struktur skala gaji & 14 & 14 & 23 & 42 & 13 & 4 \\
Pedoman kenaikan kelas jabatan & 13 & 18 & 23 & 43 & 9 & 4 \\
Komponen gaji & 9 & 9 & 20 & 40 & 28 & 4 \\
Tunjangan kesejahteraan: & & & & & & \\
- Tunjangan kesehatan & 4 & 17 & 9 & 49 & 27 & 4 \\
- Tunjangan bonus & 0 & 0 & 14 & 40 & 52 & 5 \\
- Tunjangan hari raya & 0 & 3 & 4 & 32 & 67 & 5 \\
- Program BPJS tenaga kerja & 3 & 3 & 10 & 46 & 44 & 4 \\
- Program asuransi dana pesangon & 15 & 13 & 20 & 36 & 22 & 4 \\
\hline
\end{tabular}

Tabel 4. Persepsi responden terhadap variabel komitmen

\begin{tabular}{lcccccc}
\hline \multirow{2}{*}{ Indikator } & \multicolumn{5}{c}{ Frekuensi } & \multirow{2}{*}{ Modus } \\
\cline { 2 - 6 } & 1 & 2 & 3 & 4 & 5 & \\
\hline Affective comitment & 1 & 3 & 13 & 36 & 53 & 5 \\
Normative comitment & 0 & 3 & 17 & 43 & 43 & 5 \\
Continuance comitment & 1 & 3 & 18 & 42 & 42 & 4 \\
\hline
\end{tabular}


Tabel 5. Persepsi responden terhadap variabel produktivitas

\begin{tabular}{lccccccc}
\hline & \multirow{3}{*}{ Indikator } & \multicolumn{4}{c}{ Frekuensi } & \multirow{2}{*}{ Modus } \\
\cline { 2 - 7 } & 1 & 2 & 3 & 4 & 5 & \\
\hline Efektivitas & 1 & 2 & 7 & 44 & 52 & 5 \\
Efisiensi & 1 & 4 & 9 & 47 & 45 & 4 \\
\hline
\end{tabular}

Tabel 5. Persepsi responden terhadap variabel produktivitas

\begin{tabular}{lcccc}
\hline \multicolumn{1}{c}{ Variabel } & Sistem Penggajian & Komitmen & Produktivitas & $\mathrm{N}$ \\
\hline Sistem Penggajian & 1,00 & $0,515^{* *}$ & $0,402^{* *}$ & 106 \\
Komitmen & $0,515^{* *}$ & 1,00 & $0,851^{* *}$ & 106 \\
Produktivitas & $0,402^{* *}$ & $0,851^{* *}$ & 1,00 & 106 \\
\hline
\end{tabular}

Keterangan : $\left.{ }^{* *}\right)$ Korelasi signifikan pada level 0,01 (2-tailed)

Selanjutnya, Tabel 6 juga untuk menjelaskan bahwa hubungan antara penerapan sistem penggajian dengan produktivitas kerja karyawan adalah positif dan signifikan. Hasil uji korelasi diperoleh nilai korelasi sebesar 0,402 dengan p-value $(0,000)$. P-value lebih kecil dari alpha 5\%. Artinya, terdapat hubungan yang positif dan signifikan antara sistem penggajian dengan produktivitas. Dapat dijelaskan bahwa semakin baik persepsi karyawan terhadap sistem penggajian maka akan semakin tinggi produktivitas kerja karyawan. Hameed (2014), Ketabi dan Tahmasebi (2015), Rezaei (2015) meneliti bahwa kompensasi mempunyai pengaruh yang signifikan terhadap produktivitas kerja karyawan. Hasil studi Lawler (1983) menunjukkan sistem penggajian yang efektif akan memengaruhi tingkat produktivitas dan mutu pekerjaan karyawan. Tabel 6 juga menjelaskan bahwa hubungan antara variabel komitmen dengan variabel produktivitas kerja karyawan adalah positif dan sangat signifikan. Hasil uji korelasi diperoleh nilai korelasi sebesar 0,851 dengan p-value $(0,000)$. P-value lebih kecil dari alpha 5\%. Artinya, terdapat hubungan yang positif dan sangat signifikan antara komitmen dengan produktivitas. Dapat dijelaskan bahwa semakin tinggi komitmen karyawan terhadap perusahaan maka akan semakin tinggi juga tingkat produktivitas kerja karyawan. Dixit V (2012) meneliti bahwa ada hubungan yang sangat signifikan antara komitmen dengan produktivitas.

\section{Implikasi Manajerial}

Hasil penelitian menunjukkan sistem penggajian di perusahaan mempunyai hubungan yang kuat dengan komitmen dan produktivitas kerja karyawan. Hal ini sebagai acuan manajemen bahwa untuk meningkatkan komitmen dan produktivitas kerja karyawan melalui penerapan sistem penggajian yang baik, jelas, transparan, konsisten dan dievaluasi secara berkala. Selain itu perusahaan juga harus menjaga komitmen karyawan dengan menciptakan lingkungan kerja yang kondusif, memberikan penghargaan kepada karyawan yang berprestasi, pelatihan dan pengembangan serta kepastian hari tua. Dengan terjaganya komitmen karyawan maka akan menambah semangat dalam bekerja sehingga diperoleh produktivitas kerja yang maksimal. Penelitian juga menunjukkan bahwa dalam subindikator tunjangan kesehatan mayoritas karyawan menyatakan bahwa tunjangan kesehatan tidak mencukupi untuk kebutuhan satu tahun. Manajemen sebaiknya mengevaluasi kembali besaran tunjangan kesehatan sehingga bisa memenuhi kebutuhan kesehatan karyawan. Alternative lainnya manajemen dapat menggunakan asuransi kesehatan untuk klaim, yang besarannya disesuaikan dengan anggaran perusahaan.

\section{KESIMPULAN DAN SARAN}

\section{Kesimpulan}

Secara keseluruhan berdasarkan tehnik-tehnik pengolahan data didapatkan hasil persepsi karyawan PT Dwipahasta Utamaduta terhadap sistem pengajian yang selama ini diterapkan di perusahaan adalah mayoritas karyawan mengetahui dan memahami sistem tersebut. Karyawan menyambut baik penerapan sistem penggajian tersebut karena sistem saat ini dianggap lebih jelas dan transparan. Mayoritas karyawan beranggapan bahwa sistem ini lebih memberikan kesempatan untuk berkinerja lebih baik dan harapan karyawan untuk meningkatkan kesejahteraan kehidupannya semakin terbuka luas. Sistem yang saat ini diharapkan diterapkan secara konsisten dan dievaluasi setiap tahunnya untuk 
mengetahui apakah sistem ini masih relevan dengan kondisi perusahaan atau tidak.

Hasil analisis dapat diketahui bahwa dengan semakin baiknya penerapan sistem penggajian di perusahaan maka komitmen karyawan kepada perusahaan juga akan semakin baik, demikian juga sebaliknya.Hasil penelitian juga menunjukkan bahwa dengan semakin baiknya penerapan sistem penggajian di perusahaan maka produktivitas karyawan akan meningkat, demikian juga sebaliknya. Penerapan sistem, penggajian diperusahaan sudah diketahui, dipahami dan dirasakan pada kondisi yang sebenarnya. Namun, hubungannya dengan tingkat produktivitas tidak terlalu kuat. Faktor-faktor lain seperti suasana kerja yang kondusif, hubungan antara atasan dengan bawahan yang harmonis, pola komunikasi manajemen, pola pengembangan dan pelatihan karyawan yang baik, penghargaan secara langsung terhadap karyawan berprestasi serta penegakan aturan tata tertib kerja sekiranya faktor-faktor ini akan berhubungan kuat terhadap peningkatan produktivitas karyawan.

\section{Saran}

Manajemen disarankan selalu konsisten dalam pelaksanaan sistem penggajian yang sudah disepakati bersama dengan melaksanakannya sesuai aturan perusahaan, diawasi bersama dan dievaluasi setiap tahun untuk disesuaikan dengan situasi dan kondisi perusahaan. Manajemen juga disarankan membuat sistem penilaian kinerja yang jelas sehingga dapat digunakan untuk mengukur tingkat produktivitas karyawan. Untuk penelitian selanjutnya dapat diteliti mengenai faktor-faktor apa saja yang dapat memengaruhi komitmen dan produktivitas kerja karyawan sehingga dapat membantu manajemen untuk membuat suatu kebijakan sistem penggajian yang lebih baik lagi atau sistem lainnya yang dapat secara langsung memengaruhi komitmen dan produktivitas kerja karyawan.

\section{DAFTAR PUSTAKA}

Anvari R, Amin SM, Ahmad UNU, Seliman S, Garmsari M. 2011. The Relationship between strategic compensation practices and affective organizational commitment. Interdisciplinary Journal of Research in Business (1)1:44-55

Allen NJ, Meyer JP. 1997. Coomitment in The
Workplace Theory Research and Application. California: Sage Publications.

Dewi VF. 2014. Pengaruh kompensasi terhadap produktivitas kerja pegawai pada kantor dinas perindustrian, perdagangan, koperasi dan UMKM Samarinda. Journal Ilmu Adminstrasi Bisnis 2(2):230-244.

Djarwanto PS. 2001. Mengenal Beberapa Uji Statistik dalam Penelitian. Yogyakarta: Liberti Yogyakarta.

Dixit V, Bhati M. 2012. A study abaout commitment an its impact on sustained productivity in indian auto-componen industy. European Journal of Business and Social Sciences 1(6):34-51.

Hameed A. 2014. Impact of compensation on employee performance (empirical evidence from banking sector of Pakistan). International Journal of Business and Social Science 5(2):302-309.

Huang SM, Lai WH. 2014. A study of the effect of incentive system on job performancelocus control as a moderator. The Journal of International Management Studies 9(1):89-98.

Katua NT, Mukulu E, Gachunga HG. 2014. Effect of reward an compensation strategies of the performance of commercial banks in Kenya. International Journal of Education and Research 2(1):1-20.

Ketabi A, Tahmasebi P. 2015. Effect of four dimensions of compensation system on staffs' organizational commitmen at district 2 of Iranian Gas Transmission Co. (case study: Pataveh \& Dorahan Compressor Gas Stations). GMP Review 16:346-358.

Kibisu PA, Muturi1 W, Elijah CM. 2014. Effect of reward systems on employees' achievement of targets in the semi autonomous government agencies: a case study of migori sub-country. International Journal for Innovation Education and Research 2(11):184-208.

Lawler EE. 1983. Pay and Organization Development. USA: Addison-Wesley Publishing Company Inc,

Mangkuprawira, 2002. Manajemen Sumber Daya Strategik. Jakarta: Penerbit Ghalia Indonesia.

Osa IG, Amos IO. 2014. The impact of organizational commitment on employees productivity: a case study of nigeria brewery, PLC. International Jorunal of Research in Business Management 2(9):107-122.

Onyije OC. 2015. Effect of performance appraisal on empolyee productivty in a Nigerian University. 
Journal of Economics and Business Research 21(2):65-81.

Rezaei M, Moattar FJ, Tajeri M. 2015. The impact of payroll management on employee productivity and efficiency media organizations. International Journal of Review in Life Sciences 5(4):547551.

Rizal M, Idrus MS, Djumhir, Mintarti, R. 2014. Effect of compensation on motivation, organizational comitment an empoyee performance (studies at local revenue management in Kendari City). International Journal of Business and Management Invention 3(2):64-79.

Saqib S, Abrar M, Sabir HM, Bashir M, Baig SA. 2015. Impact of tangible and intangible rewards on organizational commitment: evidence from the textile sector of Pakistan. American Journal of Industrial and Business Management 5:138-147. http//dx.doi.org/10.4236/ajibm.2015.53015.

Siagian SP. 1995. Teori Motivasi dan Aplikasinya. Jakarta: Rineka Cipta.

Simamora H. 1999. Manajemen Sumber Daya Manusia, Edisi ke-2 Cetakan ke-2. Yogyakarta: STIE YKPN.
Umar G. 2010. The Infuence of compensation on performance of sales representatives of pharmaceutical companies base in Ilorin-Nigeria. An International Multi-Discliplinary Journal Ethiopia 4(3b):223-239.

Umar H. 2005. Riset Sumber Daya Manusia dalam Organisasi (Edisi Revisi dan Perusahaan). Jakarta: PT Gramedia Pustaka Utama

Wekesa JN, Nyaroo S. 2013. Effect of compensation on performance of public secondary school teachers in eldoret municipality Kenya. International Journal of Scientific and Research Publications 3(6):1-4.

Wiantara KA. 2015. Hubungan tingkat upah dengan produktivitas kerja pada perusahaan kecap sumber rasa di Desa Temukus Tahun 2014. Jurnal Pendidikan dan Pengajaran 5(1):1-10.

Wilfred ON, Elijah CM, Muturi W. 2014. Effect of remuneration on employees performance in the ministry of internal security: a case of Kisii County. International Journal of Human Resource Studies 4(1):223-231.doi:10.5296/ ijhrs.v4i1.5478

Yamoah EE. 2013. Relationship Between Compentation and Employee Productivity. Singapore Journal Of Business Economics, And Management Studies 2(1):110-114. 